ISSN: 1838-3815 (online) Journal Homepage: https://ojs.deakin.edu.au/index.php/itlge/

\title{
Graduates' employability skills in East Africa
}

\author{
Lourdes Guàrdia $^{1}$, Federica Mancini ${ }^{1}$, Pedro Jacobetty ${ }^{1}$ and Marcelo Maina ${ }^{1}$ \\ Corresponding author: Federica Mancini (fmancini0@uoc.edu ) \\ ${ }^{1}$ Psychology and Educational Sciences Department, Universitat Oberta de Catalunya
}

\begin{abstract}
This paper reports a study about the perceptions of the academic community, employers and civil servants regarding graduates' employability skills in East Africa. Specifically, it focuses on the mismatch between skills acquired in Higher Education (HE) and those in demand by employers, and explores factors influencing the situation. A mixed method approach was implemented including a survey and a set of focus groups. The questionnaire on employability skills was distributed among regional stakeholders attending the Open Day events organised by three East African HE Institutions. A Principal Components Analysis was applied for the categorisation of the most in-demand skills and the identification of four major workplace skill sets. To gain further insights into the stakeholders' perceptions of the graduate employability skills gap, 11 focus groups were organised at the same universities. The general results showed that employability skills were mostly perceived as insufficiently developed during the students' progress in their programs. The final results enabled a better understanding of the nuanced relationship between labour market valuation and graduates' acquisition of each skill set. It also allowed us to identify problems and barriers, and suggest possible solutions to overcome the shortcomings experienced by the sub-Saharan HE system.
\end{abstract}

Keywords:

East Africa, higher education, skills gap, employability, employability skills, competences, labour market, graduates

\section{Introduction}

In 2015, world leaders and intergovernmental, philanthropic, human rights and private organisations partnered to draft the Sustainable Development Goals (UN General Assembly, 2015). Among these goals, sustainable development is related to the creation of jobs that pay reasonable wages and promote the development of new skills (E4D/SOGA, 2020; Wild \& Omingo, 2020). In this scenario, the debate on graduates' readiness to contribute to the economy through work has become increasingly prominent leading the HE agenda to set graduate employability as one of its priorities (Tomlinson, 2017).

Despite the global compromise to improve the quality of the skills of the workforce and align them to market demands, unemployment and informality in the labour market are major problems for the developing countries of Sub-Saharan Africa (SSA) (International Labour Organization [ILO], 2020a). The unemployment rate grew from 18 million in 2010 to more than 26 million in 2020 according to the estimations of the ILO WESO Data Finder ${ }^{1}$, while informal employment referring to the economic activities by workers and economic units that are - in law or in practice - not covered or insufficiently 
covered by formal arrangements' (ILO, n.d. para. 4) is essentially the norm, affecting $89.2 \%$ of workers in the Sub-Saharan region.

The extant literature reveals concerns on the missing link between graduates' skills and employers' requirements at the workplace (Arias, Evans, \&Santos, 2019; Hayward \& Ncayiyana, 2014) in the SSA region. Improving young people's employability skills is critical, as noted by Betcherman and Khan (2015), given the region's large youth bulge and the potential development spillovers that go along with a productive and engaged youth cohort (p.1).

In this paper, we explore the skills gap among graduates in the SSA region by capturing the perspective of local stakeholders involved in the EPICA² (Strategic Partnership for the Co-Design of an Innovative and Scalable ePortfolio) project. The term skills gap has been used in this study to indicate the mismatch between the skills in demand by employers in the labour market and those of the workforce, while the term employability is used to refer to the possession of relevant knowledge, skills and other attributes that facilitate the gaining and maintaining of worthwhile employment (McCowan, 2014, p.4). Employability is distinct from but related to employment (Holmes, 2017) which refers to the number of graduates employed and the types of jobs they do. Finally, the notion of employability skills is used in this study to designate the attributes that graduate students possess and which are valued by employers, i.e. attributes which make graduates worth employing.

The next section of this paper presents a literature review on the graduates' skills gap in the African continent and more specifically in SSA. The section summarises relevant aspects related to the skills demand and supply as well as the main factors impacting the graduates' skills gap. The methods section discusses the methodological approach and the procedures used for data collection and analysis, including the description of the sample involved in quantitative and qualitative data gathering. The results section is divided into three parts: the first part presents the perception of local stakeholders on the SSA graduates' readiness for work gathered through a questionnaire, the second part focuses on the outcomes of a principal component analysis on employability skills and presents the resulting dimensions, and the third part provides a detailed analysis of stakeholders' perceptions of the employability skills gap by dimension including the results obtained from a set of focus groups. We conclude by providing some recommendations for HE institutions and policymakers as well as for further research on this topic.

\section{Literature review}

Sub-Saharan graduates face the challenge of finding qualified work whilst employers report dissatisfaction with their skills and competencies (Crossman \& Clarke, 2010; ILO, 2020b). The ILO (2020a) also reveals that despite formal qualifications, young workers lack the actual skills demanded by employers while in some cases they are even over-skilled for their current jobs.

In the Inter-University Council for East Africa (IUCEA) meeting held in 2015 it was emphasized that the challenges of graduates in meeting current labour market expectations are due to the lack of important skills such as communication, decision making and problem-solving skills (Kalufya \& Mwakajinga, 2016). Moreover, corporations operating in the African continent also point out the challenge of finding appropriately trained graduates with complex skills and cognitive flexibility (Leopold, Ratcheva, \& Zahidi, 2017).

Fenta et al. (2019) underline that graduates' transition from higher education to the workplace is a multidimensional phenomenon that is subjected to several parameters. One of them envisages the level of development of generic skills (interpersonal skills, communication skills, time management skills, teamwork ability, and internship engagement). According to Choi, Dutz and Usman (2020), generic skills and high-end skills are increasingly gaining importance in the Sub-Saharan region also to maintain a momentum of innovation. However, the low level of human capital is hindering this goal. STEM (Science, Technology, Engineering and Mathematics) skills, for example, are crucial in the region to pursue innovation and creating conditions for job creation and expansion. Data analysis, computer science and engineering skills are growing in demand in Africa (Leopold et al., 2017) but

Guàrdia, L., Mancini, F., Jacobetty, P., \& Maina, M. (2021). Graduates' employability skills in East Africa. Journal of Teaching and Learning for Graduate Employability, 12(2), 169-184. 
only about $19 \%$ of students in Sub-Saharan Africa are enrolled in STEM-related programs (Choi et al., 2020). In this scenario, companies have very little interest in hiring fresh graduates and prefer to retain workers with sufficient training and experience in the company (Jiboku, 2018).

On the other side, industries currently lack highly skilled positions for graduates and a recent employment analysis reveals that only $12.3 \%$ of workers are employed in occupations that are classified as high-skilled following the ISCO-08 classification (ILO, 2020a). In this context, young workers more than others face deeply ingrained work deficits. The level of optimism about future graduate opportunities also varies based on their field of study: the majority of those who acquire a highly qualified job studied business or information technology, leaving other degrees lacking in work aspirations (Leopold et al., 2017). The scarce quality of jobs is also determined by the difficulties for governments to attract investments that could offer highly skilled positions even if regional governance stability has been steadily improving in the last years (World Economic Forum, 2017).

The challenge of youth unemployment is also raised by the growth of the working-age population in Africa. According to the African Development Bank (AfDB, 2019), the continent's youth population is projected to increase by 105 million people by 2030 with 94 million living in the sub-Saharan region (ILO, 2017). As such, the large number of young workers who enter the African labour market every year makes the need to create employment opportunities even more pressing. Numerous publications highlight the importance of finding ways to benefit from this rapid working-age population growth instead of perceiving this trend as an employability problem (Africa-America Institute [AAI], 2015; Leopold et al., 2017).

Among various solutions discussed, education plays the most significant role, as data from different sources (Awad, 2020; ILO, 2020b; Organisation for Economic Co-operation and Development [OECD], 2011) highlight the positive relationships among educational attainment level and employment rate and status in work. Higher and better levels of education, therefore, can facilitate entry into better jobs.

Good quality youth employment, however, is not only related to the level of preparation, but also to the appropriateness of the competences developed (ILO, 2020b). In fact, it is often reported that the lack of employability skills is one of the major constraints to expanding employment (Fox \& Gandhi, 2021). In addition, the African Development Bank (2019) commented as follows:

Other developing countries show a fairly competitive labour market structure, Africa has a more segmented labour market. Segmented labour markets tend to improve with economic policies that facilitate labour mobility, a competitive environment for private sector operations, and better skill development programmes (p. 17).

Likewise, the World Economic Forum white paper (2019) advocates that an effective employability strategy for the new economy must consider the integration of a skills approach to learning and in the workforce ecosystem, together with providing an enabling environment through alignment between different stakeholder groups (p.2). On the supply side of the labour market, therefore, skills and education mismatches are among the most pressing policy concerns suggesting that skills development needs to become a central strand of national policy-making (ILO, 2020a). As such, after decades of neglect, HE is finally on the development agenda of African policymakers (Manji et al., 2015).

Nevertheless, despite the recognition of the importance of a skills approach to learning, Sub-Saharan Africa has not sufficiently invested in tertiary education as government spending is severely limited. For this reason, the demand for HE caused by a growing population and increased rates of secondary school completion is much higher than the existing offer of quality HE courses. In fact, this pressure has been perceived to lower the quality of tertiary education (McCowan, 2014) and it is no wonder that the provision of quality HE is being outstripped by the growth in demand (Manji et al., 2015). In this context, overcrowding in lecture halls at some African universities is becoming all too common (AAl, 2015), while curriculum and teaching methods fail to integrate non-cognitive skills and 
employability knowledge (Fox \& Gandhi, 2021). Therefore, while the offer of HE programmes is growing in the African continent, these do not always translate into new curricula targeting the development of employability skills.

The literature also identifies shortcomings in HE when it comes to the practical application of skills as one of the main causes behind graduates' gap in employability skills. Universities tend to provide theoretical rather than practical skills in most fields (McCowan, 2015), a worrying fact since practical experience is another important factor for employability (Bhorat, Naidoo, \& Ewinyu, 2017). Many lecturers lack the proper qualifications and training, and as a consequence resort to relying on rotelearning methodologies based on memorisation. The result is limited analytical and transferable skills development at the HE level (Leopold et al., 2017) and no long-term sustainable innovation is possible without correcting this course (Choi et al., 2020).

This view is confirmed by Sparreboom and Staneva (2014), who point out that a significant number of young people in low-income countries such as Tanzania are not yet benefiting fully from the education system and are therefore unable to move towards the development of important employability skills and better labour market outcomes. According to Mgaiwa (2021), this gap is partly due to the fact that Tanzania's universities and their degree programs have been nonreactive to the changing priorities of the country's development plans. Likewise, Ngoma and Dithan Ntale (2016) claim that skills inadequacy in Uganda is mostly due to the failure of universities to convey appropriate employability skills through students' career training, poor social networking orientation, and insufficient preparation of graduates to face challenges.

Kalei (2016), who analysed the situation in Kenya, also claimed that young people do not possess the knowledge and skills required by employers as the local education system is mainly focused on achieving good grades in examinations rather than in taking into account the broader needs of the country over time. In this regard, Kalei (2016) also highlights the pressure for students to pass exams in order to receive a certificate and argues that the Kenyan education system is so focused on learners obtaining good marks that it denies the opportunity to acquire the desired skills for the job market.

Fenta et al. (2019) reveal that marks or academic grades are one of the factors affecting entry-level employment, especially when the number of job-seekers is usually much higher than the number of vacancies. Nevertheless, field-specific skills and soft skills are crucial for a successful transition from education to work (Siraye et al., 2018). Similarly, the Inter-University Council for East Africa (IUCEA) and the East Africa Business Council (EABC) highlighted the gaps in skills training in universities, the low quality of university careers services and the urgency for academic institutions to improve the monitoring of graduates for labour market outcomes as core aspects to improve (Kerre, Kitima, \& Mwawaza, 2014).

Students in Kenya also cited an irrelevant curriculum as one of the main reasons behind shortcomings in graduates' employability skills (Njeg'ere Kabita \& Ji, 2017). In terms of ICT, for example, even if graduates acquire technical knowledge in ICT, the skills they are taught are often out of date or irrelevant, and not on a par with the latest technologies (McCowan et al., 2016). To cope with this evidence, Kalufya and Mwakajinga (2016) stress the need to link the curriculum with the demand-side sector and to place employability strategies at the core of teaching and learning to ensure students take a consistent range of employability skills on board.

Additionally, the findings of a study carried out in Tanzania on the perspective of final year students and employers in relation to their employability skills proficiency and preparedness for employment emphasized the relevance of internships, work placements and work-based learning as an effective opportunity for equipping graduates with employment-relevant skills, knowledge and awareness of employer culture (Kalufya \& Mwakajinga, 2016). A list of reports from Ghana, Kenya, Nigeria and South Africa also claimed that internships and even volunteering have a positive impact on students' employability prospects (Walker, 2015). As such, work-integrated learning (WIL) which refers to educational activities integrating academic learning of a discipline with its practical application in the

Guàrdia, L., Mancini, F., Jacobetty, P., \& Maina, M. (2021). Graduates' employability skills in East Africa. Journal of Teaching and Learning for Graduate Employability, 12(2), 169-184. 
workplace, responds at least in part to the dilemma of designing a contemporary curriculum aligned with current industry practice and to prepare students to work (Whelan, 2017).

The issue related to the employability skills that graduates are currently acquiring through HE tuition and their relevance for the workplace, therefore, cannot be solely addressed using a business approach, but requires innovation in teaching and learning, reaching youth in and out of educational institutions and involving different stakeholders. According to Kalei (2016), links between universities and business/industry can be enormously helpful in facilitating graduate employability. The involvement of stakeholders in an active social dialogue at the national, sectorial and local level is key to aligning supply-driven skills development with the demand of the job market (Guardia, Maina, \& Mancini, 2021; ILO, 2020b). With this goal in mind, Fenta et al. (2019) recommend as a further study the analysis of the mismatch between the skills acquired by graduates while at university and the skills demanded by the industries as it is one of the key factors responsible for the difficulty in finding employment.

\section{Methods}

This empirical study applied a mixed methods approach following the Mixed Methods Appraisal Tool (MMAT) recommendations (Hong et al., 2019). Said approach is typically employed to address multidimensional research questions by selecting and integrating the most appropriate techniques (Teddlie \& Tashakkori, 2010). A survey was used to explore whether or not graduates were equipped with the right skills and which employability skills showed a more marked gap. A set of focus groups were also implemented to identify nuances and deeper meanings on the reasons behind the perceived skills gap.

A questionnaire was designed to answer the following research questions:

- How do stakeholders perceive the employability of graduates?

- What does the skills gap identified by stakeholders in graduate students consist of?

The quantitative data was gathered through paper-based questionnaire forms based on a convenience sample during Open Day events held in three East-African universities: the Open University of Tanzania, Makerere University in Uganda, and Maseno University in Kenya. The intention of these events was to engage in a dialogue with local stakeholders on the purpose of the project. Stakeholders were invited to participate by the local partners on the basis of their role, experience and interest in the project's goals.

The questionnaire explored whether graduates were equipped with the right skills for employment. Respondents were given a list of skills and asked to rate them using a four-point Likert scale according to how valuable they believed they were for the labour market. Finally, respondents were asked to rate the same skills according to how much they felt they had been developed throughout $\mathrm{HE}$, using a similar scale. The list of employability skills provided in the questionnaire is based on the taxonomy elaborated by the 'Skill up project - Good practices in connecting workplace and learning in higher education' (Ornellas, Falkner, \& Edman Stålbrandt, 2019). This taxonomy focuses on key skills for success in the workplace that should be developed mainly through HE courses -basic skills and those acquired throughout professional life remain excluded. The exploratory quantitative approach provides a baseline for identifying patterns and trends, as well as for organising our main arguments. These findings were then synergised with the results obtained in the focus groups, where nuances emerged and deeper meanings could be identified.

The questionnaire explored whether graduates were equipped with the right skills for employment. Respondents were given a list of skills and asked to rate them using a four-point Likert scale according to how valuable they believed they were for the labour market. Finally, respondents were asked to rate the same skills according to how much they felt they had been developed throughout $\mathrm{HE}$, using a similar scale. The list of employability skills provided in the questionnaire is based on the taxonomy elaborated by the Skill up project - Good practices in connecting workplace and learning in

Guàrdia, L., Mancini, F., Jacobetty, P., \& Maina, M. (2021). Graduates' employability skills in East Africa. Journal of Teaching and Learning for Graduate Employability, 12(2), 169-184. 
higher education (Ornellas et al., 2019). This taxonomy focuses on key skills for success in the workplace that should be developed mainly through HE courses - basic skills and those acquired throughout professional life remain excluded. The exploratory quantitative approach provides a baseline for identifying patterns and trends, as well as for organising our main arguments. These findings were then synergised with the results obtained in the focus groups, where nuances emerged and deeper meanings could be identified. A total of 89 respondents participated in the survey: 18 from Kenya, 44 from Tanzania, 25 from Uganda and two additional respondents who withheld their origin. Although the participation of three universities from different countries assures diversity and strengthens our interpretations, academics represent a more significant number. Despite this limitation, the study contribution lies in an exploratory mapping and an indepth exploration of the skill gap in a context where sources of information are scarce. Our research is exploratory and does not seek to thoroughly quantify the studied phenomena.

Table 1: Profile of the Respondents to the Survey

\begin{tabular}{lll}
\hline Role & N & Percentage \\
\hline Academic staff & 52 & 58 \\
Business community & 9 & 10 \\
Public sector & 13 & 15 \\
Students & 5 & 6 \\
No answer & 10 & 11 \\
\hline Total & $\mathbf{8 9}$ & $\mathbf{1 0 0}$
\end{tabular}

With the purpose of enriching and further clarifying the findings from the questionnaire, 11 focus groups were organised during the Open Days events. Hence, two additional research questions were formulated:

- What are the reasons behind the perceived skills gap among the region's graduates?

- What local initiatives are already in place to address graduates' skills gap?

The participants of the focus groups were selected from the scientific and educational community (including students), the business community, and the public sector, ensuring a balanced participation of stakeholders (see Table 2). Four focus groups were set up in Makerere University in Uganda, three in Maseno University in Kenya, and four in the Open University of Tanzania, involving over 20 people per institution.

The duration of each session was one hour. The discussion focused on the skills required or valued by employers in today's and the future African labour market, personal perceptions of recent graduates' readiness for entering the labour market, and new graduates' skill shortages. The qualitative analysis was conducted using Atlas.ti, Computer Aided Qualitative Data Analysis Software (CAQDAS). A first, more general level of categorisation (primary codes) for the qualitative analysis emerged from the main concerns of the research (e.g. skills valued in the labour market, skills developed in $\mathrm{HE}$, skills gap explanatory factors). The second level of categorisation (sub-codes) involved second-order tags related to the elements that had emerged during the qualitative data analysis, which helped complete the analytical framework with the participants' contributions. Subcodes were assigned after a primary code to provide greater detail and level of specificity for categorisation and analysis (Gibbs, 2018; Miles \& Huberman, 1994). This paper presents the concepts and ideas that were most significant and relevant for the stakeholders that participated in the focus groups. 
Table 2: Profile of the Participants in the Focus Groups

\begin{tabular}{|c|c|c|c|}
\hline University & № Focus Groups & № Participants & Profile \\
\hline Maseno & 3 & 22 & $\begin{array}{ll}\text { - } & \text { students (7), } \\
\text { - } & \text { academics (8), } \\
\text { - } & \text { business community (5) } \\
\text { - } & \text { public sector (2) }\end{array}$ \\
\hline Makarere & 4 & 30 & $\begin{array}{ll}\text { - } & \text { academics (7) } \\
\text { - } & \text { students (5) } \\
\text { - } & \text { business community (8) } \\
\text { - } & \text { public sector (10) }\end{array}$ \\
\hline OUT & 4 & 27 & $\begin{array}{ll}\text { - } & \text { academics }(11) \\
\text { - } & \text { students (9) } \\
\text { - } & \text { business community (3) } \\
\text { - } & \text { public sector }(5)\end{array}$ \\
\hline
\end{tabular}

\section{Results}

\section{Graduates' readiness for work}

According to our survey data, there is a generalised perception of a partial skills gap among graduates. The vast majority $(80 \%)$ of respondents considered graduates to be equipped with employability skills to some degree (Table 2 ). Only $10 \%$ of respondents identified graduates to be ready for employment, whereas an equal proportion of respondents said they were not.

\section{Table 3: Employability Skills}

\begin{tabular}{|c|c|c|c|c|}
\hline & & To some & & \\
\hline & No & degree & Yes & Total \\
\hline $\begin{array}{l}\text { Graduates equipped with adequate skills for } \\
\text { employment }\end{array}$ & $11 \%$ & $80 \%$ & $10 \%$ & $100 \%$ \\
\hline
\end{tabular}

Partial insufficiencies at the level of employability skills were also confirmed by the qualitative analysis. The majority of focus group participants from the three Sub-Saharan countries agreed that there was a skills gap, or at least that the skills graduates acquired in HE are not exactly those required by employers.

In the focus groups, the most mentioned factor behind the present skills gap was the emphasis HE programmes place on theory at the expense of practical skills development. Participants claimed graduates acquire theoretical knowledge which cannot be easily applied to professional practices. They also mentioned that the HE system trains graduates to handle common professional general activities but not to efficiently solve those corresponding to specific contexts.

Participants indicated that outdated programmes and unqualified teaching staff were also accountable for the skills gap. Curricula are not frequently reviewed, they claimed, whereas the labour market is dynamic. Participants from Kenya stated that teachers do not find support to further develop, and there were no opportunities for them to connect with industries for continuous professional development. 
A small number of groups in Kenya and Tanzania highlighted the lack of standards in universities, indicating that it is difficult to establish whether universities are issuing certifications correctly. In addition, our interlocutors in Kenya stated that curriculum design is left to the teacher alone, without any support to assist them on whether or not international standards are met.

Another reason for the skills mismatch identified by focus group participants was related to the shortage of services and programmes connecting students and employers. Participating universities do not have robust alumni services, job boards, industry liaison offices or technology transfer offices. In addition, there are few initiatives to foster entrepreneurship, mobility and internationalisation. Participants in Tanzania argued that industry associations do not take an active role in connecting employers, HE institutions and training organisations. They also mentioned the lack of governmental support.

Lastly, a group of participants from Kenya stated that the massification of HE had resulted in overloaded facilities and equipment, preventing graduates from developing their skills. They also claimed massification negatively impacted the connections between students and employers: despite government efforts to facilitate connections, finance internships and job placement services, it is not possible to meet student demand.

\section{Employability skills in graduates}

The quantitative analysis sought to understand if there were any identifiable patterns in terms of labour market skills valuation by regional stakeholders. We performed a dimension reduction technique called principal component analysis (PCA), which combines several variables into a smaller number of components that represent the most important original information. The objective of PCA is to reduce redundancy in variables and meaningless noise in the dataset. PCA was employed on the skill taxonomy created by the 'Skill Up' project, comprising 16 skills (Ornellas et al., 2018, pp. 21-22). Participants were asked to rank the labour market valuation of each skill in a four-point Likert scale. The goal of conducting the PCA in our study is to identify patterns in how respondents valued those skills. It allowed us to group variables together, thus summarizing skill valuation data and supporting the creation of the skill typology we employed in our analysis.

The PCA was performed in the R programming language (version 3.4.0) using the principal component analysis ('principal') function of the Procedures for Psychological, Psychometric, and Personality Research ('psych') package (version 1.8.4). The adequacy of using PCA in our sample was confirmed using the Kaiser-Meyer-Olkin (KMO) test with an overall value of 0.81 and the same measure for each variable with a minimum value of 0.72 (the minimum acceptability threshold is 0.6). We performed PCA using the varimax orthogonal rotation method, which helps clarify PCA results, and retained four components representing the original 16 skills. Using Cronbach's alpha $(\alpha)$, we tested the internal consistency of our approach for grouping skills. All identified skill groups presented acceptable reliability ( $\alpha$ ranged between 0.65 and 0.84 ), following Hair et al. (2014) where 0.60 is acceptable in exploratory research. 
Table 4: Rotated Component Loadings

\begin{tabular}{|c|c|c|c|c|}
\hline Skills & $\begin{array}{l}\text { Knowledge } \\
\text { economy }\end{array}$ & $\begin{array}{c}\text { Uncertainty } \\
\text { management }\end{array}$ & $\begin{array}{l}\text { Leadership } \\
\text { skills }\end{array}$ & $\begin{array}{c}\text { Cognitive } \\
\text { performance }\end{array}$ \\
\hline Results-oriented performance & 0.791 & & & 0.186 \\
\hline Digital skills & 0.750 & & & 0.318 \\
\hline Foreign language & 0.730 & 0.163 & -0.118 & 0.273 \\
\hline $\begin{array}{l}\text { Cross-cultural and diversity } \\
\text { competence }\end{array}$ & 0.669 & 0.241 & 0.112 & -0.114 \\
\hline Teamwork & 0.626 & & 0.271 & -0.248 \\
\hline $\begin{array}{l}\text { The set of subject-specific } \\
\text { skills required to successfully } \\
\text { perform a specific occupation }\end{array}$ & 0.600 & 0.345 & & \\
\hline Analytical thinking & 0.475 & & 0.305 & 0.650 \\
\hline Learning to learn & 0.389 & 0.415 & 0.104 & 0.463 \\
\hline Self-management & 0.372 & 0.719 & 0.162 & \\
\hline Ability to cope with change & 0.265 & 0.645 & 0.164 & 0.228 \\
\hline $\begin{array}{l}\text { Communication and } \\
\text { interpersonal skills }\end{array}$ & 0.206 & & 0.794 & \\
\hline Stress management & & 0.851 & & 0.239 \\
\hline Conflict management & & 0.842 & 0.269 & \\
\hline Problem-solving & & 0.451 & 0.674 & 0.345 \\
\hline Creative thinking & & 0.282 & 0.344 & 0.753 \\
\hline Decision making & & 0.270 & 0.808 & 0.229 \\
\hline
\end{tabular}

The naming of the component results from the interpretation of the associated variables (see variable loadings for each principal component in Table 4). The first component is associated with Results-oriented performance, Digital skills, Foreign language, Cross-cultural and diversity competence, Teamwork, and The set of subject-specific skills required to successfully perform a specific occupation. This component was named 'Knowledge economy' to illustrate how these skills are related to proactivity, technological knowledge, and competencies needed to work in a culturally and linguistically diverse context. The second component is associated with Stress management, Conflict management, Self-management and Ability to cope with change. The connection between these skills is the ability to maintain performance under personal and environmental uncertainty, which would explain the naming of this component as 'Uncertainty management'. The third component is mostly associated with Decision making, Communication and interpersonal skills, and Problem solving. These skills were interpreted as being aspects of 'Leadership'. Finally, the last component is associated with Creative thinking, Analytical Thinking, and Learning to learn, which we considered to be elements of 'Cognitive performance'.

This analysis refers to the second research question: which skills do stakeholders mostly consider to be missing. Overall, we observe that (1) the skill gap is less prominent in the skills related to leadership, (2) there's a moderate gap in cognitive performance skills, and (3) the gap is most marked for uncertainty management skills. The gap in knowledge economy skills seems to vary

Guàrdia, L., Mancini, F., Jacobetty, P., \& Maina, M. (2021). Graduates' employability skills in East Africa. Journal of Teaching and Learning for Graduate Employability, 12(2), 169-184. 
significantly between the associated individual skills. The next section presents this analysis in further detail, connecting the results from our survey with the analysis of focus groups.

\section{Employability skills gap by dimension}

The following analysis shows the percentage of respondents who considered the skills in the survey to be valuable for the labour market in spite of not being explicitly taught in $\mathrm{HE}$, thus proving that there is a skills gap between labour market demand and HE provision. It is clear that most respondents considered all skills to be significant.

\section{Knowledge economy skills}

\section{Table 5: Knowledge Economy skills}

\begin{tabular}{|c|c|c|c|}
\hline & Skills gap ${ }^{i}$ & $\begin{array}{l}\text { Valuable in the } \\
\text { Labour Market }\end{array}$ & $\begin{array}{l}\text { Not acquired in } \\
\text { Higher Education }\end{array}$ \\
\hline Foreign language & $45 \%$ & $85 \%$ & $57 \%$ \\
\hline $\begin{array}{l}\text { Cross-cultural and diversity } \\
\text { competence }\end{array}$ & $43 \%$ & $87 \%$ & $51 \%$ \\
\hline $\begin{array}{l}\text { The set of subject-specific skills } \\
\text { required to successfully perform a } \\
\text { specific occupation }\end{array}$ & $35 \%$ & $93 \%$ & $37 \%$ \\
\hline Results-oriented performance & $29 \%$ & $95 \%$ & $31 \%$ \\
\hline Digital skills & $24 \%$ & $97 \%$ & $26 \%$ \\
\hline Teamwork & $24 \%$ & $100 \%$ & $24 \%$ \\
\hline
\end{tabular}

' [Percentages of respondents who seemed to indicate a skills gap -i.e. who considered the associated skill to be important for the labour market ("Moderately Important" or "Very important" for employers) and not taught in higher education (who either "Disagree " or "Strongly disagree" graduates are currently developing the associated skill in higher education).]

iii [Percentages of respondents who considered the associated skill either "Moderately Important" or "Very important" for employers in the present and future African labour market.]

iii [Percentages of respondents who either "Disagree" or "Strongly disagree" with a statement claiming graduates are currently developing the associated skill in higher education.]

For the knowledge economy skill set (Table 5), gaps are found particularly in the Foreign language and Cross-cultural and diversity skills (around $45 \%$ of participants). These skills, however, are among the least valued for the labour market. Despite being significantly perceived as the locus of important gaps, the skills related to dealing with linguistic and cultural diversity are an aspect of the knowledge economy that is less valued in the workplace. The set of subject-specific skills required to successfully perform a specific occupation and Results-oriented performance are averagely valued in the labour market although a gap was identified by a considerable number of participants. Such findings replicate a major concern of the focus groups: practical and experiential skills are considered by some participants to be most relevant for the labour market. An emphasis on theory before practice in HE programmes was regarded by a high number of participants, mainly from Tanzania and Uganda, to be one of the main causes behind the skills gap in the region. In many cases, graduates are expected to bridge the skills gap by themselves when they start to work, adapting their own skills to the workplace. This is considered to be a waste of time for employers. Focus group results also revealed that HE focuses more on exams and qualifications than on developing useful skills. In Kenya it was stated that, from an early age, students learn to focus on 
grades and course results rather than on developing the necessary skills to be competitive in the labour market.

Finally, Digital skills and Teamwork are the most valuable skill sets in this dimension for survey respondents, and are also those which are less associated with a skills gap. According to the focus group interlocutors from the three Sub-Saharan countries, ICT skills are highly valued in the African labour market. As one participant from Kenya stated: "one of the key competences is ICT skills because they are becoming the core mode of delivering services within organisations in Kenya". According to a smaller number of participants from the three countries, ICT skills are acquired in HE but students may be missing a critical view on the use of technology. In terms of teamwork, focus group participants tend to agree that this skill is highly valued by employers.

\section{Uncertainty management skills}

Table 6: Uncertainty Management Skills

\begin{tabular}{|c|c|c|c|}
\hline & Skills gap & $\begin{array}{l}\text { Valuable in the } \\
\text { Labour Market }\end{array}$ & $\begin{array}{l}\text { Not acquired in } \\
\text { Higher Education }\end{array}$ \\
\hline Stress management & $55 \%$ & $89 \%$ & $64 \%$ \\
\hline Conflict management & $38 \%$ & $87 \%$ & $49 \%$ \\
\hline $\begin{array}{l}\text { Ability to cope with } \\
\text { change }\end{array}$ & $35 \%$ & $97 \%$ & $38 \%$ \\
\hline Self-management & $33 \%$ & $94 \%$ & $34 \%$ \\
\hline
\end{tabular}

Uncertainty management skills are those in which the skills gap is larger (Table 6). For each of these skills, a gap is identified by at least one third of respondents. Over half of the respondents recognise a gap with Stress management, the only skills gap that is identified by such a large proportion of the sample.

Conflict management is identified as a valuable skill in the labour market by an equivalent percentage of survey respondents, but a considerably smaller proportion of our sample signals that it is not acquired in HE. Nevertheless, it still ranks high in terms of constituting a skills gap. In Uganda, focus group participants mentioned emotional intelligence as an important skill for conflict resolution: dealing with crisis and colleagues in a way that supports communication, thus avoiding the intervention of superiors, is pointed out as a skill graduates tend to lack. The Ability to cope with change and Self-management appear to be highly valued in the labour market but a considerable number of participants acknowledge they also pertain to the skills gap. One of the most salient skills related to self-management is how graduates manage their time. As one focus group participant in Kenya stated, employers value people that are ready to meet deadlines.

\section{Leadership skills}

Table 7: Leadership Skills

\begin{tabular}{|c|c|c|c|}
\hline & Skills gap & $\begin{array}{l}\text { Valuable in the } \\
\text { Labour Market }\end{array}$ & $\begin{array}{l}\text { Not acquired in } \\
\text { Higher Education }\end{array}$ \\
\hline Problem-solving & $30 \%$ & $99 \%$ & $31 \%$ \\
\hline $\begin{array}{l}\text { Communication and } \\
\text { interpersonal skills }\end{array}$ & $25 \%$ & $100 \%$ & $25 \%$ \\
\hline Decision making & $23 \%$ & $97 \%$ & $25 \%$ \\
\hline
\end{tabular}

Guàrdia, L., Mancini, F., Jacobetty, P., \& Maina, M. (2021). Graduates' employability skills in East Africa. Journal of Teaching and Learning for Graduate Employability, 12(2), 169-184. 
There seems to be near consensus about the value of all the identified Leadership skills valued in the labour market. In addition, this skill set exhibits the lowest percentage of respondents who indicate there is a skills gap (30\% or less). Problem solving appears to be the most problematic skill. In several focus groups it was considered one of the most valued skills for employers. Only $31 \%$ of participants, however, seemed to indicate that it is not acquired in $\mathrm{HE}$.

In a focus group from Kenya, the example of banking was provided as one of the particular fields that are highly reliant on numeracy and ICT skills, requiring data analysis and finding solutions to problems. The ability to code and translate business ideas into product development is also mentioned as another example of problem solving. Nevertheless, in groups from Uganda and in one from Kenya, participants stated graduates do not sufficiently acquire this skill in HE.

Communication and interpersonal skills are considered of value for the labour market by $100 \%$ of respondents, and only $25 \%$ of participants considered them not to be acquired in $\mathrm{HE}$ and to actually constitute a skills gap. The importance of communication skills for companies, namely in PR and social media marketing, was emphasised by a focus group in Kenya. The same group indicated how a lack of communication skills may prevent skilled workers from being able to express their knowledge in an interview situation, for instance, stressing its fundamental value for employability. Despite a relative satisfaction with HE in this regard, focus group participants in Uganda mentioned an issue that may suggest ways forward: graduates often seem unable to demonstrate their communicative skills during presentations due to fear, a matter which could be addressed by increasing presentation practice in HE. Interpersonal skills were also highlighted in Kenyan focus groups as an important aspect of business operations: offering satisfying customer service.

Decision making is one of the key skills for the labour market which is least considered to be the locus of a skills gap. However, this skill was identified in one Tanzanian focus group as one of the graduates' skills where there are shortages.

\section{Cognitive performance skills}

Table 8: Cognitive Performance Skills

\begin{tabular}{lccc}
\hline & Skills gap & $\begin{array}{c}\text { Valuable in the } \\
\text { Labour Market }\end{array}$ & $\begin{array}{c}\text { Not acquired in } \\
\text { Higher Education }\end{array}$ \\
\hline Creative thinking & $35 \%$ & $99 \%$ & $35 \%$ \\
Analytical Thinking & $31 \%$ & $95 \%$ & $32 \%$ \\
Learning to learn & $28 \%$ & $94 \%$ & $32 \%$ \\
\hline
\end{tabular}

Finally, a large proportion of survey respondents seemed to indicate that there is a gap in the skill set related to cognitive performance. In this skill set, Creative thinking is both the most valued skill and the skill most associated with a skills gap (35\% of respondents). In Tanzania and Uganda, focus group participants indicated that graduates should be better skilled in terms of innovation and creativity.

Analytical thinking and Learning to learn are also associated with a skills gap by a considerably smaller proportion of survey respondents (around 30\%). According to participants in the three Ugandan focus groups, analytical and critical thinking are among the skills required by employers in the region. In particular, analytical thinking was said to be required to 'see' and 'remember' what is relevant, enabling employees to make better sense of their operations. Another important component of this type of thinking, mentioned in a Kenyan focus group, is the ability to perform data analysis. Finally, the idea that employees need to improve their own learning abilities was also mentioned in Kenya, particularly in the field of IT where innovation is sustained and fast-paced. 


\section{Discussion}

According to our findings, there is a marked perception among regional stakeholders of shortcomings related to the employability skills of graduates. This perceived lack is only partial, however, and may be the result of graduates' inability to demonstrate their acquired skills or to put them into practice. Our results corroborate what the existing literature highlights as potential causes behind the graduates' skills gap: an emphasis of university programmes on the development of theoretical knowledge before practical skills (Bhorat et al., 2017; Leopold et al., 2017; McCowan, 2015), unqualified teaching staff, outdated curricula in HE (Fox \& Gandhi, 2021; Njeg'ere Kabita \& Ji, 2017), and overloaded facilities (AAl, 2015; Manji et al., 2015; McCowan, 2014). In addition, our focus group analysis also indicates that $\mathrm{HE}$ tends to offer management-oriented training instead of occupational skills, does not meet international standards, and lacks connections with employers.

Through a more detailed analysis, we found that stakeholders in the region tend to value skills along four main axes or dimensions, which we named knowledge economy skills, uncertainty management skills, leadership skills and cognitive performance skills. In terms of knowledge economy skills, gaps are mostly related with foreign language and cross-cultural/diversity competence. As we have discussed, this is an obstacle to participation in global value chains of knowledge intensive economic production, which the literature relates to greater prosperity. The gap for the operative, occupationspecific skills is pointed out by a smaller but still significant number of survey respondents. The main causes are teaching staff disconnected from today's knowledge and practices at industry level, and highly theoretical HE programmes that lack practical focus. On the other hand, stakeholders seem to agree that graduates possess valuable skills from the knowledge economy skill set, namely resultsoriented performance, digital skills and teamwork. However, they also mentioned that a critical perspective on ICT is missing, despite not considering this a serious skills gap. Thus, this particular aspect of ICT should be improved in HE courses. Most skills linked to uncertainty management are associated with gaps by a high percentage of survey respondents. This result highlights the lack of soft skills such as those related to keeping a positive attitude and the ability to deal with conflict, change and uncertainty.

Lastly, leadership and cognitive performance skills are less associated with a skills gap, indicating the ability of HE to train good managers with interpersonal and decision-making skills, foster analytical thinking and autonomous learning, and provide theoretical knowledge to approach problems in professional contexts.

\section{Conclusion}

Our research sought to understand how university staff, employers and public civil servants in East Africa, perceive the relationship between the skills graduates acquire throughout their studies and those valued by the labour market. Our study shows that there is a marked skills gap in the region, albeit a partial one, mostly felt in some of the general knowledge economy employability skills and uncertainty management skills, but less so in leadership and cognitive performance skills. As a final note, we highlight the importance of critical engagement with the definition of graduate skills and competencies. This process provides HE institutions with the opportunity of becoming agents of social transformation by identifying problems and educating for positive impact. The findings of this study also point to the active involvement of all stakeholders working together towards the same purpose of employability. Particularly, findings support the need for universities to develop and enhance graduate skills in their programmes of study.

\section{Endnotes}

${ }^{1}$ https://bit.ly/3gfaREC

2 [EPICA (Strategic Partnership for the Co-Design of an Innovative and Scalable ePortfolio) project website: https://www.epica-initiative.com/l

Guàrdia, L., Mancini, F., Jacobetty, P., \& Maina, M. (2021). Graduates' employability skills in East Africa. Journal of Teaching and Learning for Graduate Employability, 12(2), 169-184. 


\section{References}

Africa-America Institute. (2015). State of education in Africa report, 2015: A report card on the progress, opportunities and challenges confronting the African education sector. http://www.aaionline.org/wpcontent/uploads/2015/09/AAI-SOE-report-2015-final.pdf

African Development Bank. (2019). African Economic Outlook 2019. https://www.afdb.org/fileadmin/uploads/afdb/Documents/Publications/2019AEO/AEO 2019-EN.pdf

Arias, O., Evans, D. K., \& Santos, I. (2019). The Skills Balancing Act in Sub-Saharan Africa: Investing in Skills for Productivity, Inclusivity, and Adaptability. Africa Development Forum. https://openknowledge.worldbank.org/handle/10986/31723

Awad, A. (2020). From school to employment; the dilemma of youth in Sub-Saharan Africa. International Journal of Adolescence and Youth, 25(1), 945-964. https://doi.org/10.1080/02673843.2020.1778492

Betcherman, G., \& Khan, T. (2015). Youth employment in Sub-Saharan Africa: Taking stock of the evidence and knowledge gaps. International Development Research Centre.

https://media.africaportal.org/documents/Youth Employment Sub-Saharan Africa WEB FINAL.pdf

Bhorat, H., Naidoo, K., \& Ewinyu, A. (2017). Increasing employment opportunities: Navigating Africa's complex job market. In A. Sy \& C. Golubski, (Eds.), Foresight Africa: Top priorities for the continent in 2017 (pp. 30-31). Washington: Brookings.

Choi, J., Dutz, M., \& Usman, Z. (2020). The future of work in Africa: Harnessing the potential of digital technologies for all. World Bank. https://doi.org/10.1596/978-1-4648-1444-0

Crossman, J.E.. \& Clarke, M. (2010). International experience and graduate employability: Stakeholder perceptions on the connections. High Education, 59(5), 599-613. https://doi.org/10.1007/s10734009-9268-z

E4D/SOGA. (2020). Employment and Skills for Eastern Africa. https://www.giz.de/en/downloads/E4D_SOGA_Progress_2020.pdf

Fenta, H., Asnakew, Z.S., Debele, P.K., Nigatu, S.T, \& Muhaba, A.M. (2019). Analysis of supply side factors influencing employability of new graduates: A tracer study of Bahir Dar University graduates. Journal of Teaching and Learning for Graduate Employability, 10(2), 67-85.

Fox, L., \& Gandhi, D. (2021). Youth employment in sub-Saharan Africa. Progress and prospects. (AGI Working Paper \#28). Africa Growth Initiative at Brookings. https://www.brookings.edu/wpcontent/uploads/2021/03/21.03.24-IWOSS-Intro-paper FINAL.pdf

Gibbs, G. R. (2018). Analyzing qualitative data. SAGE Publications Ltd. (Second ed.). https://dx.doi.org/10.4135/9781526441867

Guàrdia, L., Maina, M., \& Mancini, F. (2021). Increasing the visibility of graduate students' employability skills: An ePortfolio solution addressing the skill gap. In B. C. Padilla Rodríguez \& A. Armellini (Eds.), Cases on active blended learning in higher education (pp. 253-275). IGI Global. https://www.igiglobal.com/book/cases-active-blended-learning-higher/266359

Hair, J.F., Black, W.C., Babin, B.J. \& Anderson, R.E. (2014). Multivariate data analysis, 7th Edition. Upper Saddle River: Pearson Education.

Hayward, F. M., \& Ncayiyana, D. J. (2014). Confronting the challenges of graduate education in SubSaharan Africa and prospects for the future. International Journal of African Higher Education, 1(1). https://doi.org/10.6017/ijahe.v1i1.5647

Holmes, L. (2017). Graduate employability: Future directions and debate. In M. Tomlinson \& L. Holmes (Eds.), Graduate employability in context: Theory, research and debate (pp. 359-370). Palgrave Macmillan. https://doi.org/10.1057/978-1-137-57168-7

Hong, Q.N., Pluye, P., Fabregues, S., Bartlett, G., Boardman, F., Cargo, M., Dagenais, P., Gagnon, M.P., Griffiths, F., Nicolau, B., O'Cathain, A., Rousseau, M.C., Vedel, I. (2019). Improving the content validity of the mixed methods appraisal tool: A modified e-Delphi study. Journal of Clinical Epidemiology, 111, 49-59.

International Labour Organization. (2017). Global employment trends for youth 2017: Paths to a better working future. https://www.ilo.org/wcmsp5/groups/public/---dgreports/---dcomm/--publ/documents/publication/wcms 598669.pdf

International Labour Organization. (2020a). World employment and social outlook trends 2020. https://www.ilo.org/global/research/global-reports/weso/2020/lang--en/index.htm

International Labour Organization. (2020b). Report on employment in Africa (Re-Africa) Tackling the youth employment challenge. https://www.ilo.org/wcmsp5/groups/public/---africa/---roabidjan/documents/publication/wcms 753300.pdf

International Labour Organization. (n.d.). 4.5 Informal economy workers. 
https://www.ilo.org/global/topics/wages/minimum-wages/beneficiaries/WCMS_436492/lang-en/index.htm

Jiboku, J. O. (2018). Multinational corporations and skills development in Nigeria: The case of Unilever Nigeria. AFRREV IJAH: An International Journal of Arts and Humanities, 7(1), pp. 29-40. https://doi.org/10.4314/ijah.v7i1.4

Kalei, A. (2016). University graduates' employability skills' mismatch and the labour market demands in Kenya. EPH - International Journal of Business \& Management Science, 2(10), 1--8.

Kalufya, N., \& Mwakajinga, L. (2016). Employability of graduates from higher education institutions in Tanzania. Institute of Social Work Journal, 1(2) 51-68.

Kerre, M., Kitima F.C., \& Mwawaza, S. (2014). Regional Higher Education Qualification Gaps: Vol II. Situation Composite EAC Report.

http://www.percpaceinternational.com/uploads/1/6/0/2/1602844/east africa status of higher edu cation composite situation report april 2014.pdf

Leopold, T. A., Ratcheva, V., \& Zahidi, S. (2017). The future of jobs and skills in Africa: Preparing the region for the Fourth Industrial Revolution. World Economic Forum. http://www3.weforum.org/docs/WEF EGW FOJ Africa.pdf

Manji, F., Jal, E., Badisang, B., \& Opoku-Mensah, A. (2015). The elearning Africa Report 2015. The trajectory of change - Next steps for education. ICWE.

McCowan, T. (2014). Can higher education solve Africa's job crisis? Understanding graduate employability in Sub-Saharan Africa. British Council: International Higher Education.

https://www.britishcouncil.org/sites/default/files/graduate employability in ssa final-web.pdf

McCowan, T. (2015). Students in the driving seat: Young people's voices on higher education in Africa. British Council: International Higher Education.

https://www.britishcouncil.org/sites/default/files/2.5 students-in-the-drivingseat report overview.pdf

McCowan, T., Walke, M., Fongwa, S., Oanda, I., Sifuna, D., Adedeji, S., Oyebade, S. , Ananga, E.D., Adzahlie-Mensah, V., \& Tamanja, E. (2016). Universities, employability and inclusive development: Repositioning higher education in Ghana, Kenya, Nigeria and South Africa. British Council: International Higher Education. https://www.britishcouncil.org.gh/sites/default/files/universities employability and inclusive devel opment.pdf

Mgaiwa S. J. (2021). Fostering graduate employability: Rethinking Tanzania's university practices. SAGE Open, 11(2). https://doi.org/10.1177/21582440211006709

Miles, M. B., \& Huberman, A. M. (1994). Qualitative data analysis: An expanded sourcebook (2nd ed.). Sage Publications, Inc.

Ngoma, M., \& Dithan Ntale, P. (2016). Psychological capital, career identity and graduate employability in Uganda: The mediating role of social capital. International Journal of Training and Development, 20(2), 124-139. https://onlinelibrary.wiley.com/doi/abs/10.1111/ijtd.12073

Njeg'ere Kabita, D., \& Ji, L. (2017). The why, what and how of competency-based curriculum reforms: The Kenyan experience. In-Progress Reflection No 11. UNESCO.

Organisation for Economic Co-operation and Development. (2011). Education at a Glance 2011: Highlights. https://doi.org/10.1787/eag highlights-2011-16-en

Ornellas, A., Falkner, K., \& Edman Stålbrandt, E. (2019). Enhancing graduates' employability skills through authentic learning approaches. Higher Education, Skills and Work-Based Learning, 9(1), 107-120.

Siraye, Z., Abebe, T., Melese, M., \& Wale, T. (2018). A tracer study on employability of business and economics graduates at Bahir Dar University. International Journal of Higher Education and Sustainability, 2(1), 45-63.

Sparreboom, T., \& Staneva, A. (2014). Is education the solution to decent work for youth in developing economies? Work4Youth Publication Series No. 23. International Labour Office. https://www.un.org/youthenvoy/wp-content/uploads/2014/10/Work4Youth-Publication.pdf

Teddlie, C., \& Tashakkori, A. (2010). Overview of contemporary issues in mixed methods research. In A. Tashakkori \& C. Teddlie, (Eds.), SAGE handbook of mixed methods in social \& behavioral research (2nd ed.) (pp. 1-41). SAGE Publications, Inc. https://dx.doi.org/10.4135/9781506335193

Tomlinson, M. (2017). Graduate employability in context: Charting a complex, contested and multifaceted policy and research field. In M. Tomlinson \& L. Holmes (Eds.), Graduate employability in context: Theory, research and debate (pp. 1-40). Palgrave Macmillan. https://doi.org/10.1057/978-1137-57168-7 
UN General Assembly. (2015). Transforming our world: The 2030 agenda for sustainable development (A/RES/70/1). https://www.refworld.org/docid/57b6e3e44.html

Walker, M. (2015). Student perceptions of employability and inclusive development: South Africa. British Council: International Higher Education.

https://www.britishcouncil.org/sites/default/files/2.5 student-perceptions-of-employabilityinclusivity.pdf

Whelan, M.B. (2017). Academic work-integrated learning (WIL): Reengaging teaching-focused academics with industry. Journal of Teaching and Learning for Graduate Employability, 8(1), 172-187.

Wild, J., \& Omingo, M. (2020). Graduate skills for employability in East Africa: Evolution of a skills matrix for course redesign. https://www.inasp.info/publications/skills-matrix-TESCEA

World Economic Forum. (2017). The Africa Competitiveness Report 2017.

http://www3.weforum.org/docs/WEF ACR 2017.pdf

World Economic Forum. (2019). Strategies for the new economy: Skills as the currency of the labour market. http://www3.weforum.org/docs/WEF 2019 Strategies for the New Economy Skills.pdf 